\title{
Hopes and reality: consumers' purchase intention towards whitening cream
}

\author{
Md. Monirul Islam ${ }^{1 *}$ (1) and Fathema Farjana Hani, ${ }^{1,2}$
}

\begin{abstract}
In contemporary Bangladeshi society, popularity, marriage, and status are weighed on a scale where the vital criterion is a fair complexion. Women are encouraged to use whitening cream in its colour-conscious culture. The present study identifies the factors that influence consumers' purchase intention towards whitening cream. A structured questionnaire was used to elicit feedback from 275 female respondents using the convenience sampling method. Structural equation modelling and hypotheses tests were conducted to validate the model after verifying the scale items' reliability and validity. The findings revealed that attitude, involvement, and descriptive norms were significant factors, and injunctive norms, perceived quality, and price fairness were inessential factors in explaining Bangladeshi female consumers' purchase intention. The framework used in the study can assist in product design. The study makes an important contribution to the literature by explaining why female consumers equate whiteness with beauty. Marketers should not use deceptive advertisements to influence them falsely; they should fulfil their expectations without causing harm or inciting racism.
\end{abstract}

Keywords: Female consumers, Purchase intention, Whitening cream, SEM, Bangladesh

\section{Introduction}

Asians often equate beauty with whiteness, and this concept has been commodified in the marketplace [74]. White skin is pursued as an ideal for many women in Asian cultures [40]. People consider beauty and light skin to be the core of a satisfying life. Females vainly try to reduce melanin by using skin-lightening products [31]. "Skin lightening, also known as skin bleaching and skin whitening, involves the use of topical products that contain corticosteroids, hydroquinone, mercury, and a variety of other agents to attain a lighter skin color", [71] (p. 349). Despite widespread knowledge that melanin (which produces skin pigmentation) combats the sun's ultraviolet rays, the use of skin-lightening products has gradually increased.

The idea of skin whitening is intimately associated with personal identity, self-image, and racial identification.

\footnotetext{
*Correspondence: monir-ban@sust.edu

${ }^{1}$ Department of Business Administration, Shahjalal University of Science and Technology, Sylhet 3114, Bangladesh

Full list of author information is available at the end of the article
}

Physical attractiveness is regarded as a function of white skin, and the latter has many rewards, for instance, higher self-esteem, better job opportunities and salaries, and physical and mental health [38]. The whitening frenzy abounds amongst females, their families, and society as a whole. This has in part been initiated by marketers. Advertisements show how dusky women can become fairer-skinned if they use whitening cream. Females try to tackle long-standing prejudices and assume more prominence and credibility by using whitening cream. Marketers have been very successful in convincing women of the benefits of having fair skin; whitening cream sales exceed those of Coca-Cola in India.

In Bangladesh, beauty means white skin, and this perception drives the cosmetics industry. According to the Bangladesh Cosmetics and Toiletries Manufacturers' Association (BCTMA), the cosmetics industry has experienced a compound annual growth rate of $10 \%$ in the last 15 years [75]. Despite this, there is a lack of literature on skin-whitening cream in Bangladesh. The present study addresses this shortfall by examining the multiple 
factors that influence consumers' purchase intentions in the country. As purchase intention is a crucial factor in assessing consumer behaviour, manufacturers of whitening cream may find the study of assistance when researching consumer perspectives.

\section{Literature review}

\section{Fairness: the white and the dark side}

An Indian non-governmental organisation (NGO) has conducted a campaign called "Dark is Beautiful". The campaign's director, Kavitha Emmanuel, said: "Skin colour bias affects people psychologically. It affects how children perform in school because their confidence level goes down; they feel they are not good enough. Moreover, when it comes to marriage, we again find that skin colour plays a vital role. We thought, 'why are we keeping quiet about this? We should talk about this and see how people respond"'.

Emmanuel delivered a petition containing 30,000 signatures to the Emami cosmetics company protesting their discriminatory advert for their Fair and Handsome brand. However, Emami's managing director said: “There is a need in our society for whitening creams, so we are meeting the need". He refused to withdraw it [76].

Colour-sensitive women in Bangladeshi society are so preoccupied with the issue that they apply whitening cream to their children. In Africa, Asia, and Latin American countries, women generally practise skin bleaching because they associate whiteness with social and economic benefits. Educated and working women consider whiteness as a way of competing globally with different races and ethnicities. However, no medical study has proven that whitening cream has permanent results. Not only may whiter skin be out of reach, but the use of such products could also be damaging [77].

\section{Theoretical framework and hypothesis development Purchase intention}

Purchase intention reflects consumer cognitive behaviour regarding the intention to buy specific products or brands [30]. The intensity of customers' willingness to purchase a commodity is determined by purchase intention. The greater the intensity, the stronger the purchase intention [57]. Moreover, measuring consumer buying behaviour is not straightforward, and purchase intention is crucial to assess consumer buying behaviour. Purchase intention can be used to measure the intensity of attraction towards a particular product. Moreover, stronger purchase intention directs consumers' desire to buy a product [57]. Consumer willingness and intention to indulge in a transaction is stimulated by purchase intention [50]. Measuring purchase intention is helpful in understanding which brands or products consumers will purchase [23]. Also, it is possible to assess respondents' attitudes by measuring purchase intention [47].

\section{Attitudes and purchase intention}

Attitude is defined as "a latent disposition or tendency to respond with some degree of favourableness or unfavourableness to a psychological object" [62] (p. 76) and can be applied to purchase intention towards skin-whitening cream. Multi-attribute models such as the theory of reasoned action [3] and the theory of planned behaviour [4] can be used to explore how attitude impacts purchase intention. Attitude towards an object is a consideration in the individual's evaluation of it. A positive attitude directs them towards an intention to purchase, whereas a negative attitude does the opposite [65]. Attitude is one of the principal determinants of purchase intention. Various researchers have found a connection between attitudes with behavioural intention. For instance, attitude has a positive and significant effect on purchase intention towards halal cosmetic products [1]. It was also revealed how attitudes can predict purchase intention significantly [5]. A person's attitude towards an object-be it a product or service-can influence their intention to buy or not [3]. A positive attitude towards a product is an indicator of a greater willingness to buy it [16]. Consumers' intention towards brands is influenced by their attitude, and a positive stance suggests a greater willingness to buy [15]. Positive attitudes are positively associated with consumers' e-shopping intentions [58]. A study conducted amongst 515 young Chinese consumers found that attitudes had a positive effect on purchase intention towards organic foods [2]. Exploration of consumer attributes amongst Hispanic shoppers of local foods found a positive relationship between attitude and purchase intention [12]. Research also showed how attitude was most significantly related to purchase intention towards local food [59]. In the light of the above, the following hypothesis is proposed:

H1: Consumers with a favourable attitude towards whitening cream have a higher intention to purchase.

\section{Consumer involvement and purchase intention}

Consumer involvement is defined as a person's perceived relevance of the specific products based upon inherent interest, values, and needs [72]. Product involvement is determined by how far the consumer considers the product to be important to their life [28] and their subjective evaluation of its perceived value [39]. Involvement has been described as the amount of arousal or interest that is generated by a situation, object, or stimulus; it represents an individual-level variable [45]. Product involvement generally refers to consumers' enduring perceptions of the importance of the product category based on their 
inherent needs, values, and interests [67]. Customer product selection is determined by purchase intention. The product's importance to the individual and the latter's willingness to search for information or alternatives are influenced by their product involvement (Schiffman \& Kanuk, 2005). Moreover, higher perceived usefulness directs higher involvement and purchase intention. Consumer involvement is so crucial that it is used to segment consumers [42]. The researchers identified product involvement as an indicator that is linked to product evaluation and purchasing decisions [29]. Because consumer involvement provides motivation to purchase, the consumer is likely to remain longer in a store and visit it more frequently. In other words, it impacts behaviour [66], and this creates positive intention [34]. In the light of the above, the following hypothesis is proposed:

$\mathrm{H} 2$ : Consumer involvement is positively related to purchase intention towards whitening cream.

\section{Subjective norms and purchase intention}

Subjective norms indicate feelings of morally responsible behaviour in the purchase specific products, and this is dependent on the consumers' social image [7]. Perceptions of different people's behaviour (e.g. neighbours, friends, and peers) have a persistent influence on others' behaviour, and these are considered the subjective norm [4]. Subjective norms reflect perceived social pressure to conform to a specific behaviour and in the present context contribute to forecasting intention to engage in purchasing skin-whitening cream. Previous studies have shown a strong relationship between subjective norms and purchase intention regarding different products; for instance, the intention to engage in e-commerce is influenced by subjective norms. There is a positive relationship between subjective norms and purchase intention of organic products [17]. A positive relationship between subjective norms and consumer purchase intention towards organic foods in particular is also explored [2]. Consumers' decision-making concerning product choice can be based on the influence of family and friends [70]. Also, consumers' community involvement and subjective norms positively influenced the intention to use e-commerce websites [37].

A meta-analysis of the theory of planned behaviour exposed that injunctive and descriptive norms are conceptually different constructs [44]. Conceptualisation of injunctive norms alongside the theory of planned behaviour is extensively used [62]. Injunctive norms are defined as the reflection of social pressure regarding one's conduct through the perception of others' approval or disapproval [18].

By contrast, descriptive norms are determined by others' social pressure and what is perceived as normal conduct regarding a behaviour [18]. "A majority of descriptive norms increased self-identification, positive attitudes, and self-efficacy regarding vegetable intake behaviour" [61] (p. 245). These ideas can be adapted to examine intention towards purchasing skin-whitening cream. In the light of the above, the following hypotheses are proposed:

H3: Injunctive norms are positively associated with intention to purchase whitening cream.

H4: Descriptive norms are positively associated with intention to purchase whitening cream.

\section{Perceived quality and purchase intention}

Perceived quality is the estimation made by the consumer relying on the whole set of basic as well as the outer dimension of the product or the service [25]. Perceived quality is a post-purchase construct [8]. Perceived quality is essential in the measurement of consumer requirements, especially purchase intention [60]. A positive relationship between perceived quality and purchase intention towards a firm's products and services is also identified [10]. Several studies have explored the positive impact of perceived quality on purchase intention [11]. Product perceived quality significantly impacts purchase intention. And perceived quality plays a significant role in conducting purchase intention towards international brand [63]. A cross-cultural study conducted on sports shoes in China and Korea revealed that consumers who perceive high quality will demonstrate high purchase intention [21]. Perceived quality is essential to measure consumer requirements [52] and to assess consumer behaviour, especially purchase intention [32]. A strong relationship between perceived quality and purchase intention was explored [9]. Moreover, product or service quality is an antecedent of purchase intention [11]. In the light of the above, the following hypothesis is proposed:

$\mathrm{H} 5$ : Consumers who perceive a product as being of high quality have a higher intention to purchase.

\section{Price fairness and purchase intention}

Price fairness is defined as what is reasonable, acceptable, and justifiable when compared with competitor prices [68]. Perceived price fairness is a major factor affecting product perception. It can lead to positive recommendations and influence purchase behaviour [13]. When assessing price fairness, a consumer may evaluate the derived value of the respective product, competitors' prices, the price paid by other consumers, or the pricesetting practices of the company [22]. The judgement of price fairness may include previous prices, rivals' prices, and the product itself [41]. Therefore, price fairness represents the subjective evaluation of consumers. If a price seems more affordable than their internal price standards 
or competing prices, then customers tend to have a greater purchase intention towards the product [24]. It was also found that price fairness significantly influences purchase intention and that the former is an antecedent of the latter [35]. In the light of the above, the following hypothesis is proposed:

H6: Price fairness is positively related to purchase intention towards whitening cream.

\section{Methods}

The present study's conceptual framework (Fig. 1) consisted of five key variables: attitude, involvement, subjective norms (injunctive and descriptive), perceived quality, and perceived price fairness. Data from 275 females were collected from Sylhet City. Judgemental sampling was used because the respondents were female only. Structured questionnaire was produced using Google Forms and distributed through social media and email. A total of 300 questionnaires were sent out, and 275 usable responses were inputted. This data collection method was chosen because one-to-one interviews were not possible (owing to COVID-19). The questionnaire was piloted amongst 15 female consumers who were then using whitening cream and 5 from whitening cream businessmen and 5 from expert faculty members. The final questionnaire was prepared following feedback. A conventional translation and back-translation method was used to modify the scale in Bengali. The questionnaire comprised two sections: the first contained questions regarding the participants' demographic profiles and the second contained questions regarding whitening cream. To assess the meaning of whitening to the participants, a question was adapted from [31]. The questionnaire was used to extract data for the independent and dependent variables (Table 1). The explanatory variable was purchase intention, which was measured using an item adapted from [43] and [49]. To measure the attitude of the participants towards purchase intention, the indicators were adapted from [51]. The participants' interest in whitening cream was measured by items extracted from [56]. To assess the impact of injunctive norms in purchase intention, items were adapted from [20]; and to assess descriptive norms, items were adapted from [54]. To examine the impact of perceived quality on consumer purchase intention, items were extracted from [63] and [69]. Items for measuring price fairness were adapted from [39]. All the independent and dependent variables were measured on a 7-point scale ranging from $1=$ strongly disagree to $7=$ strongly agree . The data were analysed using SPSS and AMOS 21 versions software.

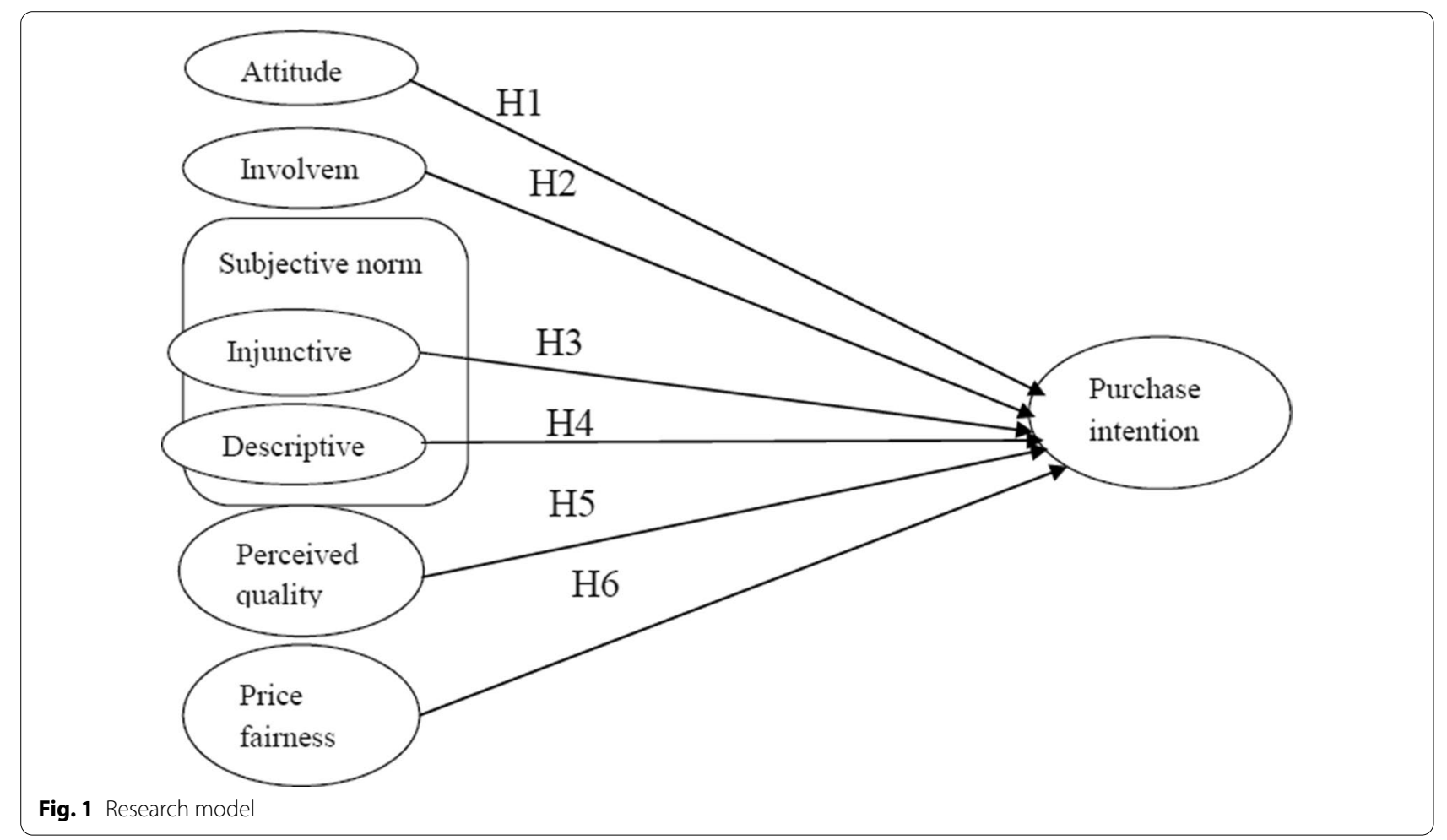


Table 1 Constructs and items

\begin{tabular}{|c|c|c|c|}
\hline Construct & Item code & Scale items & Source \\
\hline \multirow[t]{4}{*}{ Attitude } & ATT1 & Using fairness cream is a good idea & {$[51]$} \\
\hline & ATT2 & Using fairness cream is wise & \\
\hline & ATT3 & I like the idea of using fairness cream & \\
\hline & ATT4 & To me, fairness creams are pleasurable & \\
\hline \multirow[t]{4}{*}{ Involvement } & INV1 & I find it important what kind of fairness cream I am purchasing & {$[56]$} \\
\hline & INV2 & It is relevant to me to purchase fairness cream & \\
\hline & INV3 & Purchasing fairness cream means a lot to me & \\
\hline & INV4 & I find it valuable to purchase fairness cream & \\
\hline \multirow[t]{3}{*}{ Injunctive norms } & INJ1 & Most people who are important to me think that I should use fairness cream regularly & {$[20]$} \\
\hline & INJ2 & Most people who are important to me expect that I should use fairness cream regularly & \\
\hline & INJ3 & Most people who are important to me would want me to use fairness cream regularly & \\
\hline \multirow[t]{4}{*}{ Descriptive norms } & DN1 & It is important to know other people's attitude regarding fairness cream & {$[54,55]$} \\
\hline & DN2 & If other peoples purchase fairness cream, then it will be sensible to purchase fairness cream & \\
\hline & DN3 & Most people like me are using fairness cream regularly & \\
\hline & DN4 & Most people who are important to me use fairness cream regularly & \\
\hline \multirow[t]{5}{*}{ Perceived quality } & PQ1 & Fairness cream has a good functional quality & {$[63,69]$} \\
\hline & PQ2 & Materials used in fairness cream are effective & \\
\hline & PQ3 & I am not price sensitive if the product quality is good & \\
\hline & PQ4 & Quality is my main concern when purchasing fairness cream & \\
\hline & PQ5 & Fairness cream gives me what I want & \\
\hline \multirow[t]{5}{*}{ Price fairness } & PF1 & I think price is important when purchasing fairness cream & [39] \\
\hline & PF2 & I compare prices of different brands when purchasing fairness cream & \\
\hline & PF3 & The price of the fairness cream is acceptable & \\
\hline & PF4 & The price of the fairness cream is fair & \\
\hline & PF5 & The price of the fairness cream is reasonable & \\
\hline \multirow[t]{5}{*}{ Purchase intention } & Pl1 & I intend to buy fairness cream in the near future & {$[43,49]$} \\
\hline & $\mathrm{Pl} 2$ & I will try to buy fairness cream in the near future & \\
\hline & $\mathrm{Pl} 3$ & I will make an effort to buy fairness cream in the near future & \\
\hline & $\mathrm{Pl} 4$ & I plan to buy fairness cream regularly & \\
\hline & $\mathrm{Pl} 5$ & I expect to buy fairness cream regularly & \\
\hline
\end{tabular}

\section{Results}

\section{Respondents' demographic characteristics}

Table 2 presents information about the respondents. Most of the participants $(n=275)$ were aged between 15 and 25 (53.1\%), and most (73.82\%) had an income below BDT20,000. Students accounted for $62.55 \%$ of the sample. Of the 275 participants, 53.82\% had attended university. The majority $(74.18 \%)$ of the participants were single.

Exactly $98.18 \%$ of the respondents were users of whitening cream. The other $1.82 \%$ were not currently, but they intended to; $84.36 \%$ preferred foreign whitening creams. A little under half (44.72\%) of the participants preferred to purchase their creams from a specialty beauty store. They stated that they used them to change their skin colour from black/brown to fair.

\section{Descriptive, correlation, and discriminant validity}

Prior to the further test, the descriptive statistics and correlation matrix for all the variables were evaluated. The correlation matrix shows that the variables were positively correlated and significant at the 0.01 level. The diagonal shaded and bold numbers show the square root of the average. The other values in the respective columns and rows show that all were below the square root value, thus indicating that there were no issues regarding discriminate validity (Table 3 ).

\section{Reliability and validity of data}

Reliability and validity analyses were conducted before the model and hypotheses tests. Cronbach's alpha was used to assess the reliability of the measurement scales. The results were satisfactory, so the study could be run. 
Table 2 Respondents' information

\begin{tabular}{|c|c|c|c|}
\hline Characteristics & Category & Frequency & Per cent \\
\hline \multirow[t]{4}{*}{ Age } & $15-25$ & 146 & $53.1 \%$ \\
\hline & $26-35$ & 79 & 28.73 \\
\hline & $36-45$ & 31 & $11.27 \%$ \\
\hline & $46+$ & 19 & $6.90 \%$ \\
\hline \multirow[t]{4}{*}{ Income } & Below 20,000 tk & 203 & $73.82 \%$ \\
\hline & 21,000 tk. $-40,000$ tk & 56 & $20.36 \%$ \\
\hline & 41,000 tk. $-60,000$ tk & 11 & $4 \%$ \\
\hline & Above $60,000 \mathrm{tk}$ & 5 & $1.82 \%$ \\
\hline \multirow[t]{4}{*}{ Education } & Higher secondary or less & 72 & $26.18 \%$ \\
\hline & University students & 148 & $53.82 \%$ \\
\hline & Graduate & 50 & $18.18 \%$ \\
\hline & Postgraduate & 5 & $1.82 \%$ \\
\hline \multirow[t]{4}{*}{ Occupation } & Student & 172 & $62.55 \%$ \\
\hline & Self-employed & 9 & $3.27 \%$ \\
\hline & Job holder & 29 & $10.55 \%$ \\
\hline & Housewife & 65 & $23.64 \%$ \\
\hline \multirow[t]{2}{*}{ Marital status } & Single & 204 & $74.18 \%$ \\
\hline & Married & 71 & $25.82 \%$ \\
\hline \multirow[t]{2}{*}{ Use experience fairness cream } & Yes & 270 & $98.18 \%$ \\
\hline & No & 5 & $1.82 \%$ \\
\hline \multirow[t]{2}{*}{ Preferred product } & Local & 43 & $15.64 \%$ \\
\hline & Foreign & 232 & $84.36 \%$ \\
\hline \multirow[t]{4}{*}{ Point of purchase } & Departmental store & 114 & $41.45 \%$ \\
\hline & Specialty beauty store & 123 & $44.72 \%$ \\
\hline & Online & 26 & $9.45 \%$ \\
\hline & Others & 12 & $4.36 \%$ \\
\hline \multirow[t]{4}{*}{ Meaning of skin whitening } & Changing the skin colour from black/brown to fair & 123 & $44.72 \%$ \\
\hline & Removing unwanted marks on the skin & 31 & $11.27 \%$ \\
\hline & Cleansing the skin deeply & 10 & $3.64 \%$ \\
\hline & Getting vivid and radiant skin & 111 & $40.36 \%$ \\
\hline
\end{tabular}

Source: Primary data

Table 3 Descriptive, correlation matrix, and square root of AVE

\begin{tabular}{|c|c|c|c|c|c|c|c|c|c|}
\hline Construct & Mean & SD & ATT & INV & INJ & DN & $P Q$ & PP & PI \\
\hline ATT & 5.7467 & 1.05528 & .71 & & & & & & \\
\hline INV & 5.8173 & .99153 & $.341^{* *}$ & .75 & & & & & \\
\hline INJ & 5.6873 & 1.03467 & $428^{* *}$ & $.256^{* *}$ & .79 & & & & \\
\hline DN & 6.0991 & .90591 & $.182^{* *}$ & $.236^{* *}$ & $.202^{* *}$ & .84 & & & \\
\hline$P Q$ & 6.0564 & .79775 & .094 & $.196^{* *}$ & $.152^{* *}$ & $.702^{* *}$ & .85 & & \\
\hline PP & 6.0745 & .86359 & $.289^{* *}$ & $.155^{* *}$ & $.228^{* *}$ & $.183^{* *}$ & $.107^{*}$ & .82 & \\
\hline $\mathrm{PI}$ & 6.0788 & .90049 & $.369^{* *}$ & $.371^{* *}$ & $.293^{* *}$ & $.303^{* *}$ & $.209^{* *}$ & $.148^{* *}$ & .81 \\
\hline
\end{tabular}

**Sig. at the 0.01 and *. Sig. at the 0.05 level.

Sources primary data

An acceptable reliability coefficient is 0.70 , but lower thresholds have been used in the literature [48]. Although the generally accepted value is at least 0.70 , values lower than 0.60 are also acceptable for exploratory studies [26]. The communality value of each item was above 0.50 . All the factor loading was equal to or higher than 0.64 , and 
the average variance extracted (AVE) of each construct was higher than 0.50 (Table 4), which represents the threshold value [6].

Therefore, the measurement scale items' convergent validity was achieved. Internal consistency of the measurement scales was verified by using composite reliability, which was above 0.70 , and therefore this met the threshold level suggested by researchers [26].

\section{Model fit}

The confirmatory factor analysis (CFA) results of the estimated structural model and fit indices provided by AMOS indicated the proposed model's adequacy to fit with the data (Table 5). $\mathrm{X}^{2}=896.324$ with $\mathrm{df}=254$, $p<0.05 ; \quad$ RMSEA $=0.076, \quad$ TLI $=0.951, \quad$ CFI $=0.962$, $\mathrm{NFI}=0.935, \mathrm{AGFI}=0.953, \mathrm{GFI}=0.963$. These are considered acceptable [64]. Also, the small value of RMR indicated a model fit. The columns labelled LO 90 and HI 90 contain the lower and upper limits of a $90 \%$ confidence interval for the value of RMSEA (Table 5).

\section{Testing the hypotheses}

Based on the data analysis, standardised path coefficients (Fig. 2) and $p$ values (Table 6) were provided. Hypothesis 1, which proposed that consumers with a favourable attitude towards whitening cream have a higher intention to purchase, was confirmed (path coefficient of 0.341 and $p$ value $=0.004$ ). Hypothesis 2 , which

Table 4 Reliability and validity of data

\begin{tabular}{|c|c|c|c|c|c|c|c|}
\hline Constructs & Item code & Communalities & Loading & Eigen values & Cronbach's a & $\mathrm{CR}$ & AVE \\
\hline \multirow[t]{3}{*}{ Attitude } & ATT1 & 0.648 & 0.636 & 7.205 & 0.682 & 0.76 & 0.51 \\
\hline & ATT2 & 0.696 & 0.726 & & & & \\
\hline & ATT3 & 0.661 & 0.772 & & & & \\
\hline \multirow[t]{4}{*}{ Involvement } & INV1 & 0.629 & 0.736 & 3.748 & 0.783 & 0.84 & 0.56 \\
\hline & INV2 & 0.628 & 0.736 & & & & \\
\hline & INV3 & 0.681 & 0.751 & & & & \\
\hline & INV4 & 0.691 & 0.775 & & & & \\
\hline \multirow[t]{3}{*}{ Injunctive norms } & INJ1 & 0.756 & 0.805 & 20.454 & 0.763 & 0.83 & 0.62 \\
\hline & INJ2 & 0.739 & 0.775 & & & & \\
\hline & INJ3 & 0.675 & 0.778 & & & & \\
\hline \multirow[t]{4}{*}{ Descriptive norms } & DN1 & 0.934 & 0.849 & 1.706 & 0.958 & 0.90 & 0.70 \\
\hline & DN2 & 0.875 & 0.849 & & & & \\
\hline & DN3 & 0.885 & 0.819 & & & & \\
\hline & DN4 & 0.838 & 0.824 & & & & \\
\hline \multirow[t]{4}{*}{ Perceived quality } & PQ1 & 0.908 & 0.905 & 1.491 & 0.934 & 0.91 & 0.72 \\
\hline & PQ2 & 0.856 & 0.862 & & & & \\
\hline & PQ3 & 0.878 & 0.874 & & & & \\
\hline & PQ4 & 0.703 & 0.743 & & & & \\
\hline \multirow[t]{4}{*}{ Price fairness } & PF1 & 0.799 & 0.847 & 1.108 & 0.848 & 0.89 & 0.67 \\
\hline & PF2 & 0.757 & 0.862 & & & & \\
\hline & PF3 & 0.646 & 0.764 & & & & \\
\hline & PF4 & 0.698 & 0.793 & & & & \\
\hline \multirow[t]{3}{*}{ Purchase intention } & Pl1 & 0.690 & 0.792 & 1.019 & 0.809 & 0.85 & 0.65 \\
\hline & $\mathrm{Pl} 2$ & 0.772 & 0.833 & & & & \\
\hline & $\mathrm{Pl} 3$ & 0.688 & 0.784 & & & & \\
\hline
\end{tabular}

Source: SPSS and AMOS output by analysing primary data

Table 5 Model fit results

\begin{tabular}{lllllllllllll}
\hline$X^{2}$ & DF & X $^{2} /$ DF & P value & GFI & AGFI & NFI & CFI & TLI & RMR & RMSEA & LO 90 & HI 90 \\
\hline 896.324 & 254 & 3.529 & 0.000 & 0.962 & 0.953 & 0.935 & 0.962 & 0.951 & 0.065 & 0.076 & 0.066 & 0.082 \\
\hline
\end{tabular}

Source: AMOS output by analysing primary data 


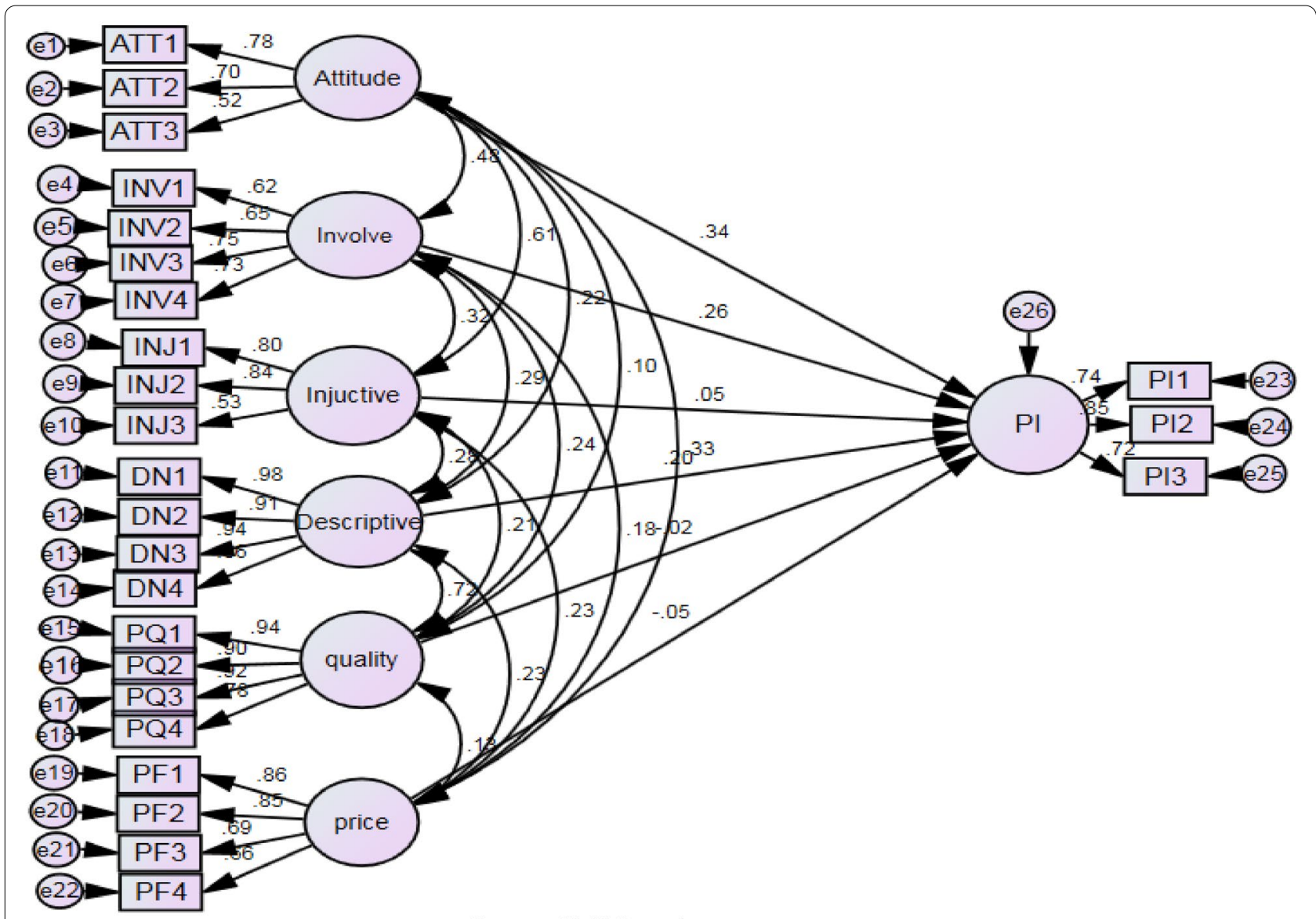

Source: AMOS result

Fig. 2 Path analysis

Table 6 Hypothesis tests (path analyses)

\begin{tabular}{lcrlll}
\hline Hypothesis & Estimate & \multicolumn{1}{l}{ C.R } & S.E & P value & Result \\
\hline $\mathrm{H} 1: \mathrm{ATT} \rightarrow \mathrm{PI}$ & 0.341 & 2.873 & 0.108 & 0.004 & Supported \\
$\mathrm{H} 2: \mathrm{INV} \rightarrow \mathrm{PI}$ & 0.255 & 3.048 & 0.070 & 0.002 & Supported \\
$\mathrm{H} 3: \mathrm{INJ} \rightarrow \mathrm{PI}$ & 0.046 & 0.493 & 0.104 & 0.622 & Not supported \\
$\mathrm{H} 4: \mathrm{DN} \rightarrow \mathrm{PI}$ & 0.204 & 2.246 & 0.078 & 0.025 & Supported \\
$\mathrm{H} 5: \mathrm{PQ} \rightarrow \mathrm{PI}$ & -0.019 & -0.213 & 0.103 & 0.831 & Not supported \\
$\mathrm{H} 6: \mathrm{PF} \rightarrow \mathrm{PI}$ & -0.047 & -0.692 & 0.065 & 0.489 & Not supported \\
\hline
\end{tabular}

Source: AMOS output by analysing primary data

proposed that consumer involvement is positively related to purchase intention towards whitening cream, was confirmed (path coefficient of 0.255 and $p$ value $=0.002$ ). Hypothesis 3, which proposed that injunctive norms are positively associated with intention to purchase whitening cream, was not confirmed (path coefficient of 0.046 and $p$ value $=0.622$ ). Hypothesis 4 , which proposed that descriptive norms are positively associated with intention to purchase whitening cream, was supported (path coefficient of 0.204 and $p$ value $=0.025$. Hypothesis 5, which proposed that consumers who perceive a product as being of high quality have a higher intention to purchase, was not supported (path coefficient of -0.019 and $p$ value $=0.831$. Finally, Hypothesis 6 , which proposed that price fairness is positively related to purchase intention towards whitening cream, was not confirmed (negative coefficient of -0.047 and $p$ value $=0.489$. In other words, the participants did not make purchase decisions based on price alone; quality may also have been considered. This finding is in keeping with [73]. It is also notable that the CR value was above 1.96, and a small standard error supported the accepted hypotheses.

\section{Robustness of the study}

For the robustness of the study, initially a number of analyses were performed. The study looked for missing data as well as univariate and multi-variate outliers. The kurtosis and skewness of the distribution for each item were used to confirm the distribution's normality. Moreover, we used Bollen-Stine bootstrap since we have a complete 
data set and used here 500 samples bootstrapping and maximum likelihood estimation, and it indicated that the testing of the model is correct. A Mahalanobis distance of 1 or less indicates that the point is in the middle of the benchmark points. This study shows that all the Mahalanobis distances are less than 1. This study also used partial least square (PLS)-SEM. After evaluating the measurement model, it was confirmed that there were no concerns with reliability and validity. Then, the structural model was assessed. To perform the path analysis, 500 resamples were bootstrapped. The analysis shows that the results were similar to the AMOS SEM, where $\mathrm{H} 1, \mathrm{H} 2$, and $\mathrm{H} 4$ were accepted, and the R2 of the endogenous latent variables was 0.31 . An $r$-square value of. 12 or less indicates a small impact size, 0.13 to 0.25 indicates a medium effect size, 0.26 or more indicates a high effect size, and in this study the r-square value 0.31 suggests a high effect size [19].

\section{Discussion}

The present study aimed to explore the role of attitude, involvement, subjective norms, perceived quality, and price fairness in influencing women's purchase intention towards skin-whitening cream. An extensive review of the literature resulted in six hypotheses, from which the study's structural model was derived. This was tested by examining data collected from 275 females.

A strong positive relationship was found between attitude and purchase intention. A positive attitude was a crucial determinant. A more favourable attitude directed the participants towards positive purchase intention. The participants considered purchasing whitening cream as a good idea and thought that using it was a sensible idea. The findings relating to attitude and purchase intention were in line with previous studies[62]; [33].

The results suggested that consumer involvement had a significant relationship with purchase intention. According to the literature, consumer involvement is a strong determinant of purchase intention [14]. The participants were more involved with the type of whitening cream they were purchasing. They regarded their purchase as valuable and personally significant.

We assessed subjective norms in two parts (injunctive and descriptive). Injunctive norms were insignificant in purchase intention. This implied that the participants' purchase intentions were not influenced by the opinions of others-an insignificant relationship that confirmed previous studies [36]. A significant relationship between descriptive norms and purchase intention was revealed. This finding is supported by two other researchers [27]. It shows that the items studied under descriptive norms were strong enough to predict the participants' purchase intention. It can therefore be stated that the participants thought neither about others' approval nor disapproval of their purchasing behaviours. Following descriptive norms, people are normally interested in knowing what others do and seek to behave accordingly.

An insignificant relationship was discovered between perceived quality and purchase intention. This finding is in keeping with other research also [46]. It may have depended on situational factors because, although the supplied product or service may be of the highest standard, the participants may have had an expectation that could not be met under any circumstances.

\section{Implications}

The present study contributes to the current literature by exploring the relationship between attitudes, involvement, subjective norms, perceived quality, perceived price, and purchase intention. The positive relationship between attitude and purchase intention suggests that the participants who regarded whitening cream as practically advantageous and pleasurable had a strong intent to purchase. Therefore, to attract consumers, it is imperative to build formative attitude clues. The findings provide strong theoretical support regarding attitude formation and how it influences consumer behaviour. Attitude has significant implications for whitening cream marketing; advertisers should try to influence attitude formation clues through storytelling. But this endeavour should be undertaken ethically; marketers should not deceive consumers by suggesting that whitening cream can make them beautiful (which may have some racist undertones) or confer other advantages.

The significant relationship between descriptive norms and purchase intention suggests that the participants were interested in what other people do. To encourage purchase intention, marketers could use brand endorsements to enhance credibility. The concept of descriptive norms could be exploited to this end. Moreover, the character of the endorser is crucial here.

The significant relationship between involvement and purchase intention revealed that the participants considered whitening cream to be valuable and important. Marketers should therefore attempt to persuade noninvolved consumers to purchase by using tools such as eye-catching audio-visuals on TV advertisements, interactive billboards, scratch options on packaging for gift giveaways, and so on.

The present study clarifies issues concerning whitening products for consumers and may help marketers to track current market trends and purchase intention. It provides demographic information that will be valuable in the targeting of customers. 


\section{Limitations and future research}

The present study has several limitations. The data only covered females from Sylhet City. Because purchase intention and preferences may vary according to gender and region, future researchers could study broader populations in both respects. Also, the data were collected using non-probability convenience sampling, which means that the results cannot be generalised for that reason alone. Future studies could use probability sampling (e.g. random sampling) and carry out longitudinal studies to address this shortcoming. It would also be advisable to examine the impact of different moderating and mediating effects on a wider range of variables. The findings cannot be applied to other sectors because each industry is distinct, but the model used for the present study could be used to analyse other beauty services.

In summary, while the present study contributes to the literature on the skincare industry by providing a deeper understanding of a particular aspect of it, future researchers should address some of its shortcomings.

\section{Conclusions}

Marketers have cultivated in both men and women a latent desire to have lighter skin because of the extraordinary advantages this is considered to confer. In future, the focus should be on nourishing, cleansing, and rejuvenating skin rather than making it white. Also, the government should take steps to regulate the production of harmful creams. High prices could deter consumers from purchasing products that are a health hazard. There are some signs that marketers are changing their approach. For instance, Dove promotes the idea of real beauty, an admirable initiative that may help to shift the paradigm [53].

The present study offers insights into customer purchase intention towards whitening cream by investigating the relationship between multiple variables (i.e. attitude, involvement, injunctive and subjective norms, perceived quality, and price fairness) and participants' purchase intention. The results reveal that perceived quality, price fairness, and injunctive norms had an insignificant relationship with purchase intention. By contrast, attitude, descriptive norms, and involvement had a significant relationship with purchase intention. The present study provides the basis on which to build a customer-centric approach towards the question of purchase intention. The information it provides will help both marketers and scholars in their work. Marketers can explore the factors that are crucial in encourage consumers to buy whitening products-intention in particular. Accurate perception of consumer purchase intention can give firms the power to set premium prices and secure consumer loyalty. Meanwhile, scholars can use the study as a foundation on which to investigate different populations, related ethical issues, and so on.

\section{Abbreviations}

SEM: Structural equation modelling; AMOS: Analytical moment of structures; SPSS: Statistical Package for the Social Sciences; AVE: Average variance extracted; CFA: Confirmatory factor analysis; DF: Degrees of freedom; RMSEA: Root-mean-square error of approximation; TLI: Tucker-Lewis index; RMR: Rootmean-square residual; GFI: Goodness-of-fit index; AGFI: Adjusted goodnessof-fit index; CFI: Comparative fit index; NFI: Normed fit index; CR: Composite reliability; SE: Standard error; PLS: Partial least square.

\section{Author details}

${ }^{1}$ Department of Business Administration, Shahjalal University of Science and Technology, Sylhet 3114, Bangladesh. ${ }^{2}$ Department of Business Administration, North East University Bangladesh, Sylhet 3100, Bangladesh.

Received: 17 January 2021 Accepted: 31 August 2021

Published: 1 November 2021

\section{References}

1. Ahmad AN, Rahman AA, Rahman SA (2015) Assessing knowledge and religiosity on consumer behavior towards halal food and cosmetic products. Int J Soc Sci Humanit 5:10-14. https://doi.org/10.7763/ijssh.2015.v5. 413

2. Ahmed N, Li C, Khan A, Qalati SA, Naz S, Rana F (2021) Purchase intention toward organic food among young consumers using theory of planned behavior: role of environmental concerns and environmental awareness. J Environ Plan Manag 64:796-822. https://doi.org/10.1080/09640568. 2020.1785404

3. Ajzen I, Fishbein M (1980) Understanding attitudes and predicting social behavior. Prentice-Hall, Englewood Cliffs, NJ

4. Ajzen I, Driver BL (1991) Prediction of leisure participation from behavioral, normative, and control beliefs: an application of the theory of planned behavior. Leis Sci 13:185-204. https://doi.org/10.1080/01490 409109513137

5. Asif M, Xuhui W, Nasiri A, Ayyub S (2018) Determinant factors influencing organic food purchase intention and the moderating role of awareness: a comparative analysis. Food Qual Prefer 63:144-150. https://doi.org/10. 1016/j.foodqual.2017.08.006

6. Bagozzi RP, Yi Y (1988) On the evaluation of structural equation models. J Acad Mark Sci 16:74-94. https://doi.org/10.1007/BF02723327

7. Barber NA, Bishop M, Gruen T (2014) Who pays more (or less) for proenvironmental consumer goods? Using the auction method to assess actual willingness-to-pay. J Environ Psychol 40:218-227. https://doi.org/ 10.1016/j.jenvp.2014.06.010

8. Bell SS, Holbrook MB, Solomon MR (1991) Combining esthetic and social value to explain preferences for product styles with the incorporation of personality and ensemble effects. J Soc Behav Personal 6:243-274

9. Bilal M (2013) Factors influencing consumers purchase intentions towards private brands. J Indep Stud Res Soc Sci Econ 11:17-28. https:// doi.org/10.31384/jisrmsse/2013.11.2.2

10. Bou-Llusar JC, Camisón-Zornoza C, Escrig-Tena AB (2001) Measuring the relationship between firm perceived quality and customer satisfaction and its influence on purchase intentions. Total Qual Manag 12:719-734. https://doi.org/10.1080/09544120120075334

11. Boulding W, Kalra A, Staelin R, ZeithamI VA (1993) A dynamic process model of service quality: from expectations to behavioral intentions. $J$ Mark Res 30:7. https://doi.org/10.2307/3172510

12. Campbell J (2013) Antecedents to purchase intentions for Hispanic consumers: a "local" perspective. Int Rev Retail Distrib Consum Res 23:440-455. https://doi.org/10.1080/09593969.2013.796565

13. Campbell MC (1999) Perceptions of price unfairness: antecedents and consequences. J Mark Res 36:187-199. https://doi.org/10.2307/3152092

14. Chan JCF, Jiang Z, Tan BCY (2010) Understanding online interruptionbased advertising: impacts of exposure timing, advertising intent, and 
brand image. IEEE Trans Eng Manag 57:365-379. https://doi.org/10.1109/ TEM.2009.2034255

15. Chaniotakis IE, Lymperopoulos C, Soureli M (2010) Consumers'intentions of buying own-label premium food products. J Prod Brand Manag 19:327-334. https://doi.org/10.1108/10610421011068568

16. Cheah I, Phau I (2011) Attitudes towards environmentally friendly products: the influence of ecoliteracy, interpersonal influence and value orientation. Mark Intell Plan 29:452-472. https://doi.org/10.1108/02634 501111153674

17. Chuchinprakarn S (2005) Application of the Theory of Reasoned Action to On-line Shopping. Na N/A:1-7

18. Cialdini RB, Reno RR, Kallgren CA (1990) A focus theory of normative conduct: recycling the concept of norms to reduce littering in public places. J Pers Soc Psychol 58:1015-1026. https://doi.org/10.1037/0022-3514.58.6. 1015

19. Cohen J (1992) Statistical power analysis. Curr Dir Psychol Sci 1:98-101. https://doi.org/10.1111/1467-8721.ep10768783

20. Dunn Kl, Mohr P, Wilson CJ, Wittert GA (2011) Determinants of fast-food consumption. an application of the theory of planned behaviour. Appetite 57:349-357. https://doi.org/10.1016/j.appet.2011.06.004

21. Eunju K, Kim KH, Zhang H (2008) A cross cultural study of antecedents of purchase intention for sports shoes in Korea and China. J Glob Acad Mark Sci 18:157-177. https://doi.org/10.1080/12297119.2008.9707281

22. Ferguson JL, Ellen PS (2013) Transparency in pricing and its effect on perceived price fairness. J Prod Brand Manag 22:404-412. https://doi.org/ 10.1108/JPBM-06-2013-0323

23. Fitzsimons GJ, Morwitz VG (1996) The effect of measuring intent on brand-level purchase behavior. J Consum Res 23:1-11. https://doi.org/10. 1086/209462

24. Frans van Waarden, Robin van Dalen (2010) Hallmarking Halal Regulating Halal: a Case of-as yet_-Private Regulation. Third Bienn Conf ECPR Standing Groups Regul Gov 1-43

25. Grunert KG (2005) Food quality and safety: Consumer perception and demand. Eur Rev Agric Econ 32:369-391. https://doi.org/10.1093/eurrag/ jbi011

26. Hair JF, Black WC, Babin BJ, Anderson RE, Tatham RL (1998) Multivariate Data Analysis. Prentice Hall, Upper Saddle River

27. Ham M, Jeger M, Ivković AF (2015) The role of subjective norms in forming the intention to purchase green food. Econ Res Istraz 28:738-748. https://doi.org/10.1080/1331677X.2015.1083875

28. Han MC, Kim Y (2017) Why consumers hesitate to shop online: perceived risk and product involvement on Taobao.com. J Promot Manag 23:24-44. https://doi.org/10.1080/10496491.2016.1251530

29. Hochgraefe C, Faulk S, Vieregge M (2012) Links between swiss hotel guests' product involvement and brand loyalty. J Hosp Mark Manag 21:20-39. https://doi.org/10.1080/19368623.2011.584265

30. Hosein DNZ (2015) Measuring the purchase intention of visitors to the auto show. J Manag Mark Researc 9:1-17

31. Hossain M (2020) Attitudes of the Female University Students towards Skin Whitening in Bangladesh. Epidemiol Int J. https://doi.org/10.23880/ eij-16000134

32. Keller KL (2001) Building customer-based brand equity : a blueprint for creating strong brands building customer-based brand equity : a blueprint for creating strong brands. J Mark Commun 15:139-155. https://doi. org/10.1080/13527260902757530

33. Kim HY, Chung JE (2011) Consumer purchase intention for organic personal care products. J Consum Mark 28:40-47. https://doi.org/10.1108/ 07363761111101930

34. Kim J, Fiore AM, Lee HH (2007) Influences of online store perception, shopping enjoyment, and shopping involvement on consumer patronage behavior towards an online retailer. J Retail Consum Serv 14:95-107. https://doi.org/10.1016/j.jretconser.2006.05.001

35. Konuk FA (2018) Price fairness, satisfaction, and trust as antecedents of purchase intentions towards organic food. J Consum Behav 17:141-148. https://doi.org/10.1002/cb.1697

36. Kumar B (2012) A Theory of Planned Behaviour Approach to Understand the Purchasing Behaviour for Environmentally Sustainable Products. Indian Institute of Management, Ahmedabad

37. Lal P (2017) Analyzing determinants influencing an individual's intention to use social commerce website. Futur Bus J 3:70-85. https://doi.org/10. 1016/j.fbj.2017.02.001
38. Langlois JH, Kalakanis L, Rubenstein AJ, Larson A, Hallam M, Smoot M (2000) Maxims or myths of beauty? A meta-analytic and theoretical review. Psychol Bull 126:390-414. https://doi.org/10.1037/0033-2909. 126.3.390

39. Ledikwe A, Stiehler-Mulder B, Roberts-Lombard M (2020) Product involvement, WOM and eWOM in the fast food industry: a young adult perspective in an emerging African economy. Cogent Bus Manag. https://doi. org/10.1080/23311975.2020.1817288

40. Li EPH, Min HJ, Belk RW, Kimura J, Bahl S (2008) Skin lightening and beauty in four Asian cultures. Adv Consum Res 35:444-449

41. Bolton LE, Warlop L, Alba JW (2003) Consumer Perceptions of Price (Un) Fairness. J Consum Res 29:474-491

42. Lockshin LS, Spawton AL, Macintosh G (1997) Using product, brand and purchasing involvement for retail segmentation. J Retail Consum Sery 4:171-183. https://doi.org/10.1016/s0969-6989(96)00048-3

43. Madden TJ, Ellen SP, Ajzen I (1992) Madden 1992. Personal Soc Psychol Bull 18:3-9

44. Manning M (2009) The effects of subjective norms on behaviour in the theory of planned behaviour: A meta-analysis. Br J Soc Psychol 48:649-705. https://doi.org/10.1348/014466608X393136

45. Mittal B, Lee MS (1989) A causal model of consumer involvement. J Econ Psychol 10:363-389. https://doi.org/10.1016/0167-4870(89)90030-5

46. Mohd RS, Suhardi WM, Anita AH, Maznah WO, Etty HH (2013) The relationship between product quality and purchase intention: the case of Malaysias national motorcycle/scooter manufacturer. African J Bus Manag 5:8163-8176. https://doi.org/10.5897/ajbm11.267

47. Nedungadi $P$ (1990) Recall and consumer consideration sets: influencing choice without altering brand evaluations. J Consum Res 17:263. https:// doi.org/10.1086/208556

48. Nunnally JC (1978) Psychometric theory, vol 2. McGraw-Hill, New York

49. Nystrand BT, Olsen SO (2020) Consumers' attitudes and intentions toward consuming functional foods in Norway. Food Qual Prefer 80:103827. https://doi.org/10.1016/j.foodqual.2019.103827

50. Pavlou PA (2003) Consumer acceptance of electronic commerce: Integrating trust and risk with the technology acceptance model. Int J Electron Commer 7:101-134. https://doi.org/10.1080/10864415.2003. 11044275

51. Petty RE, Cacioppo JT, Schumann D (1983) Central and peripheral routes to advertising effectiveness: the moderating role of involvement. J Consum Res 10:135. https://doi.org/10.1086/208954

52. Rao SS, Raghunathan TS, Solis LE (1997) A comparative study of quality practices and results in India, China and Mexico. J Qual Manag 2:235-250. https://doi.org/10.1016/s1084-8568(97)90005-5

53. Rehman V (2019) Revisiting the fairness paradigm in India. Soc Bus Rev 14:31-42. https://doi.org/10.1108/sbr-03-2018-0023

54. Rhodes RE, Blanchard CM, Matheson DH (2006) A multicomponent model of the theory of planned behaviour. Br J Health Psychol 11:119137. https://doi.org/10.1348/135910705X52633

55. Rivis $A$, Sheeran $P$ (2017) Descriptive norms as an additional predictor in the theory of planned behavior: a meta-analysis. Plan Behav Relatsh between Hum Thought Action 22:43-62. https://doi.org/10.4324/97813 15126449-4

56. Russell-Bennett R, McColl-Kennedy JR, Coote LV (2007) Involvement, satisfaction, and brand loyalty in a small business services setting. J Bus Res 60:1253-1260. https://doi.org/10.1016/j.jbusres.2007.05.001

57. Schiffman G, Kanuk L (2000) Consumer Behavior. Prentice Hall, Inc., Englewood Cliff

58. Schultz DE, Patti CH, Kitchen PJ (2013) The evolution of integrated marketing communications: the customer-driven marketplace. Evol Integr Mark Commun Cust Marketpl. https://doi.org/10.4324/9781315872728

59. Shin $\mathrm{YH}$, Hancer M (2016) The role of attitude, subjective norm, perceived behavioral control, and moral norm in the intention to purchase local food products. J Foodserv Bus Res 19:338-351. https://doi.org/10.1080/ 15378020.2016 .1181506

60. Spears N, Singh SN (2004) Measuring attitude toward the brand and purchase intentions. J Curr Issues Res Advert 26:53-66. https://doi.org/10. 1080/10641734.2004.10505164

61. Stok FM, de Ridder DTD, de Vet E, de Wit JBF (2012) Minority talks: the influence of descriptive social norms on fruit intake. Psychol Heal 27:956-970. https://doi.org/10.1080/08870446.2011.635303 
62. Sukato N, Elsey B (2009) A model of male consumer behaviour in buying skin care products in Thailand. ABAC J 29:39-52

63. Tee PK, Gharleghi B, Chan B, Samadi B, Balahmar AA (2015) Purchase intention of international branded clothes fashion among Younger's in Jakarta. Int J Bus Soc Res 5:08-17. https://doi.org/10.18533/ijbsr.v5i8.784

64. Turner LW, Reisinger $Y$ (2001) Shopping satisfaction for domestic tourists. J Retail Consum Serv 8:15-27. https://doi.org/10.1016/S0969-6989(00) 00005-9

65. Verbeke W, Vackier I (2005) Individual determinants of fish consumption: application of the theory of planned behaviour. Appetite 44:67-82. https://doi.org/10.1016/j.appet.2004.08.006

66. Wakefield KL, Baker J (1998) Excitement at the mall: Determinants and effects on shopping response. J Retail 74:515-539. https://doi.org/10. 1016/S0022-4359(99)80106-7

67. De Wulf K, Odekerken-Schröder G, lacobucci D (2001) Investments in consumer relationships: a cross-country and cross-industry exploration. J Mark 65:33-50. https://doi.org/10.1509/jmkg.65.4.33.18386

68. Xia L, Monroe KB (2010) Is a good deal always fair? Examining the concepts of transaction value and price fairness. J Econ Psychol 31:884-894. https://doi.org/10.1016/j.joep.2010.07.001

69. Yan L, Xiaojun F, Li J, Dong X (2019) Extrinsic cues, perceived quality, and purchase intention for private labels: evidence from the Chinese market. Asia Pacific J Mark Logist 31:714-727. https://doi.org/10.1108/ APJML-08-2017-0176

70. Yoh E, Damhorst ML, Sapp S, Laczniak R (2003) Consumer adoption of the internet: the case of apparel shopping. Psychol Mark 20:1095-1118. https://doi.org/10.1002/mar.10110

71. Yusuf MA, Mahmoud ND, Rirash FR, Stoff BK, Liu Y, McMichael JR (2019) Skin lightening practices, beliefs, and self-reported adverse effects among female health science students in Borama, Somaliland: a crosssectional survey. Int J Women's Dermatology 5:349-355. https://doi.org/ 10.1016/j.jijwd.2019.08.006

72. Zaichkowsky JL (1985) Measuring the Involvement Construct. J Consum Res 12:341. https://doi.org/10.1086/208520

73. Zhang B, Fu Z, Huang J, Wang J, Xu S, Zhang L (2018) Consumers' perceptions, purchase intention, and willingness to pay a premium price for safe vegetables: a case study of Beijing, China. J Clean Prod 197:1498-1507. https://doi.org/10.1016/j.jclepro.2018.06.273

74. Intersections: Whose Debt?: Globalisation and Whitefacing in Asia. http:// intersections.anu.edu.au/issue9/gooncraven.html. Accessed 13 Aug 2021

75. The economy of the fairness industry | Dhaka Tribune. https://www. dhakatribune.com/opinion/special/2019/01/26/the-economy-of-thefairness-industry. Accessed 14 Aug 2021

76. Skin-whitening creams reveal the dark side of the beauty industry | Guardian sustainable business |The Guardian. https://www.theguardian. com/sustainable-business/blog/skin-whitening-cream-dark-side-beautyindustry. Accessed 13 Aug 2021

77. Fair and growing - Economy News - Issue Date: Dec 4, 2000. https://www indiatoday.in/magazine/economy/story/20001204-skin-care-boomingsales-multiplying-brands-market-for-fairness-products-changes-colour778754-2000-12-04. Accessed 14 Aug 2021

\section{Publisher's note}

Springer Nature remains neutral with regard to jurisdictional claims in published maps and institutional affiliations.

\section{Submit your manuscript to a SpringerOpen ${ }^{\circ}$ journal and benefit from:}

- Convenient online submission

- Rigorous peer review

- Open access: articles freely available online

- High visibility within the field

- Retaining the copyright to your article

Submit your next manuscript at springeropen.com 